\title{
GEOSPATIAL MULTI-CRITERIA DECISION BASED SITE SUITABILITY ANALYSIS FOR SOLID WASTE DISPOSAL USING TOPSIS ALGORITHM
}

\author{
A. K. Jaiswal ${ }^{1, *}$, A. Satheesh T ${ }^{3}$, K. Pandey ${ }^{2}$, P. Kumar ${ }^{2}$, S. Saran ${ }^{2}$ \\ ${ }^{1}$ Indian Institute of Remote Sensing, Dehradun, India - jaiswal.akshay@ gmail.com \\ ${ }^{2}$ Indian Institute of Remote Sensing, Dehradun, India - (kamal, pramod, sameer)@iirs.gov.in \\ ${ }^{3}$ School of Planning \& Architecture, Bhopal, India - athulyasatheesht@ gmail.com
}

Commission V, SS: Infrastructure and Development Planning

KEY WORDS: Geospatial Techniques, AHP-TOPSIS, Ideal Points

\begin{abstract}
:
The problem of Urban Municipal solid waste disposal is a challenging task faced by civic bodies and planning authorities in almost all the cities of rapidly developing countries like India. A similar situation is being faced by Dehradun, the capital, and the fastest growing city of Uttarakhand, India. In the current study, an attempt has been made to find out the suitable sites for waste disposal in the area around Dehradun city using Geospatial Multi-criteria Decision Analysis (MCDA) techniques from remote sensing data. Two different decision rules of MCDA are used, namely, Analytical Hierarchical Process based Weighted Linear Combination (AHP WLC) and Technique for Order Preference by Similarity to the Ideal Solution (TOPSIS). WLC has been used previously for similar studies for its ease and simplicity to apply in raster format but TOPSIS has an advantage over WLC, it orders a set of alternatives on the basis of their separation from the ideal point. It defines the best alternative as the one that is simultaneously closest to the ideal alternative and farthest from the negative ideal point. Raster-based suitability analysis has been done and the results obtained by the two methods are compared. Identical results with minor differences identifying best suitable sites outside the eastern boundary of the city where the existing dumping site is located are obtained. Also, new potential sites are identified in the western part of the city which faces the problem of waste disposal more acutely because of expansion of the city in that direction.
\end{abstract}

\section{INTRODUCTION}

India is one of the fastest growing economies in the world (World Bank Group, 2017). As the country is advancing in all areas of development and especially infrastructure, health, education, etc. the cities are expanding and growing at exponential rates as more and more people are becoming educated and moving towards service sector. Per capita income levels are rising and so is the standard of living, unfortunately, this is leading to a massive rise in the generation of solid waste volumes and most of the cities are ill-equipped to cope with this rising pressure of solid waste generation (JNNURM, 2012). Cities face the problem of limited land resources for waste disposal sites. Moreover, unplanned and mismanaged direct disposal of solid waste leads to environmental degradation and can cause various problems such as water pollution, vectorborne diseases, bad aesthetics and foul smell, combining together into the loss of natural resources and societal displeasure (Ahmed et. al., 2006). In India generation of solid waste per head per day is between 500 and $700 \mathrm{~g}$ (Babalola, 2011). Indian cities lack a proper number of waste disposal sites and rest are suffering from quick depletion of existing sites. This has become a burning political, social and environmental issue in recent times and has led to improper, non-scientific planning and mismanagement in selecting the suitable site of solid waste disposal by civic authorities (Mohd, 2011), hence a major task to tackle for the scientific community to provide some scientific solution to the problem.

The present study has been done on the Dehradun city area, to find out suitable areas for locating new sites for disposal of solid waste making use of geospatial techniques and multi- criteria decision analysis (MCDA). It is a powerful tool when we need to combine many criteria which can lead to the outcome of a problem. It helps in quantifying the data which is quite subjective in nature. MCDA and Geographic Information System (GIS) can be combined thanks to today's modern tools available to do the spatial analysis for an area (Malczewski, 1999). In the present study, the quantification of various variables which influence the site selection for solid waste dumping is done using Analytical Hierarchical Process (AHP) presented by Saaty (1980). It helps in measuring intangibles in relative term. It compares the criteria pairwise and calculates the weights or the relative importance of each criterion (Saaty, 1977). These weights derived have been further used and combined in a GIS environment using two different algorithms, namely, Weighted Overlay Method or Weighted Linear Combination (WLC) method and also by Technique for Order Preference by Similarity to the Ideal Solution (TOPSIS) and suitable sites for Solid Waste Disposal have been found out in and around Dehradun city area. Previous attempts have been made for similar study (Sai Krishna et. al., 2017) using weighted overlay technique. The present study's goal is to find and then compare suitable sites for Solid waste dumping in the area surrounding Dehradun using Remote Sensing and GIS technology combined with MCDA algorithms WLC and TOPSIS as a continuation of the aforementioned study.

\section{STUDY AREA}

Dehradun is the capital city and administrative center of Uttarakhand, India. It lies between $29^{\circ} 58^{\prime} \mathrm{N}-31^{\circ} 2^{\prime} 30^{\prime \prime} \mathrm{N}$ and

\footnotetext{
* Corresponding author
} 
$77^{\circ} 34^{\prime} 45^{\prime \prime} \mathrm{E}-78^{\circ} 18^{\prime} 30^{\prime \prime} \mathrm{E}$. It is one of the fastest growing cities in the whole country. The city is also developing as the educational hub of the state along with numerous government institutions already existing here. The total area of the city is about $300 \mathrm{sq}$. $\mathrm{km}$. It is a tourist hub attracting massive floating population into the city that generates huge solid waste along with the ever-rising population in the city. Therefore to cater for this rising need of waste disposal a $5 \mathrm{~km}$ buffer region to the ward boundary of the city as shown in Figure 1 was taken as the study area for the present study. The total area including the buffer zone is about 700 sq. $\mathrm{km}$.

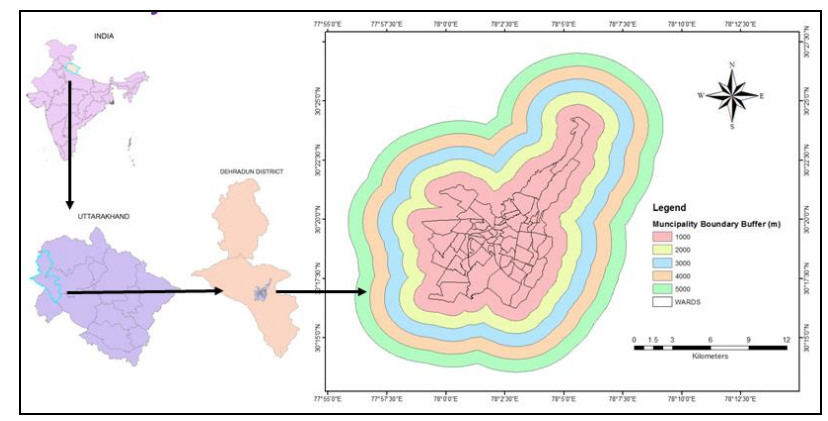

Figure 1. Study area

\section{DATA USED}

For site suitability analysis both primary and secondary data is needed. In the present study primary data includes visual interpretation of satellite imageries and then Land Use Land Cover (LULC) map preparation using supervised classification, whose details are mentioned in Table 1 . This data along with CartoDEM of $30 \mathrm{~m}$ spatial resolution was sourced from BHUVAN geoportal of National Remote Sensing Centre (NRSC). Secondary data includes soil map sourced from Soil Survey and Land Use Planning (NBSS\&LUP), Geomorphology and Lithology Maps sourced from Geological Survey of India (GSI), and drainage map prepared from Survey of India Toposheets.

\begin{tabular}{|l|c|c|c|c|}
\hline Satellite & Sensor & $\begin{array}{c}\text { Date of } \\
\text { acquisition }\end{array}$ & $\begin{array}{c}\text { Spatial } \\
\text { Resolution }\end{array}$ & $\begin{array}{c}\text { Spectral } \\
\text { Resolution }\end{array}$ \\
\hline Cartosat & PAN & $\begin{array}{c}28 \text { March } \\
2010\end{array}$ & $2.5 \mathrm{~m}$ & 1 Band \\
-1 & & $\begin{array}{c}\text { March } \\
2013\end{array}$ & $5.6 \mathrm{~m}$ & 3 Bands \\
IRS - P6 & $\begin{array}{c}\text { LISS - } \\
\text { IV }\end{array}$ & \begin{tabular}{l} 
\\
\hline
\end{tabular} \\
\hline
\end{tabular}

Table 1. Details of Remote Sensing data used

\section{METHODOLOGY}

The methodology adopted has been shown conceptually in the form of a flowchart in Figure 2. It can be broadly divided into three phases: data collection and preparation phase, design phase and choice phase.

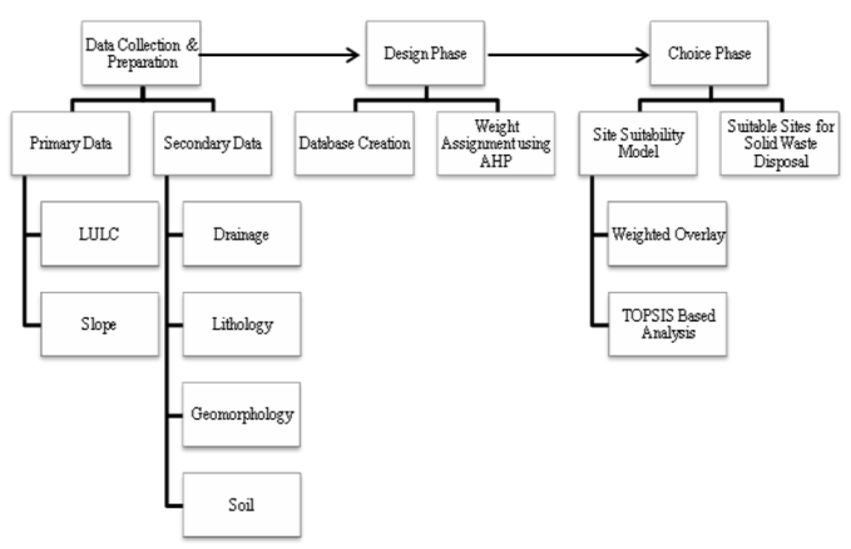

Figure 2. Methodology Flowchart

\subsection{Data Collection and Preparation Phase}

4.1.1 Primary Data: Cartosat-1 imagery was merged with LISS IV imagery to enhance the spectral resolution using resolution merge pan sharpen feature in ERDAS Imagine 2014 software. After performing image fusion the output was used for visual image interpretation and preparing LULC map using supervised classification. Also CartoDEM was used to prepare the slope map using ArcMap software which is further used as one of the input layers in the analysis.

4.1.2 Secondary Data: Selecting a suitable site for solid waste disposal depends on various criteria (Sai Krishna et. al., 2017). The different maps namely Soil, Lithology, Geomorphology and Drainage were digitized and hence rasterized in ArcMap 10.1 and used as inputs for MCDA giving suitable scores as discussed further.

\subsection{Design Phase}

A database always helps in storing data sourced from different places at one place and to do comprehensive spatial and nonspatial analysis and also prevents loss of information. Hence, an integrated geospatial solid waste database has been created to store both spatial and non-spatial data derived from various sources. Also all the datasets were generated by using the geoprocessing tools available in ArcMap such as buffer, reclassify, union, clip, etc. in to ensure that all layers are of same geographical extent and same cell size in the created thematic layers.

Further, the suitability scores were assigned to each criterion by referring to the literature and taking expert opinion and summarized in Table 2 . These six main criteria had sub-criteria which were assigned suitable scores/ weightages. The percentage of influence of each criterion was based on the importance of those criteria in determining the suitable site.

\begin{tabular}{|l|l|c|}
\hline S.No. & Main Criteria & Importance (\%) \\
\hline 1 & Soil & 22.5 \\
2 & Slope & 22.5 \\
3 & Geomorphology & 15 \\
4 & Lithology & 15 \\
5 & Land Use/ Land Cover & 15 \\
6 & Drainage & 10 \\
\hline
\end{tabular}

Table 2. Importance of each main criterion 
The main criteria had sub criteria which were given suitability score or weights ranging from 1 to 9 , where 1 represent least importance and 9 represents extremely more relative importance (Saaty, 1977)

4.2.1 Soils sub-criteria: The base soil map was sourced from NBSS\&LUP, it was digitized and clipped according to the study area in ArcMap. The soil is the most important parameter while ascertaining the suitable site for solid waste disposal, as it is the first point of contact. Sandy soils are porous and allow seepage, hence are unsuitable whereas clayey soils offer the least seepage, so are most suitable. Accordingly, weights from 1 to 9 are assigned to the different soil classes as given in Table 3 and applied spatially to soil layer as shown in Figure 3.

\begin{tabular}{|l|c|}
\hline Soil Type & Suitability Score \\
\hline Sandy and littoral soils & 1 \\
Podzolic Soils & 3 \\
Rock Outcrop & 5 \\
Skeletal Soils & 9 \\
\hline
\end{tabular}

Table 3. Suitability Scores given to each soil type

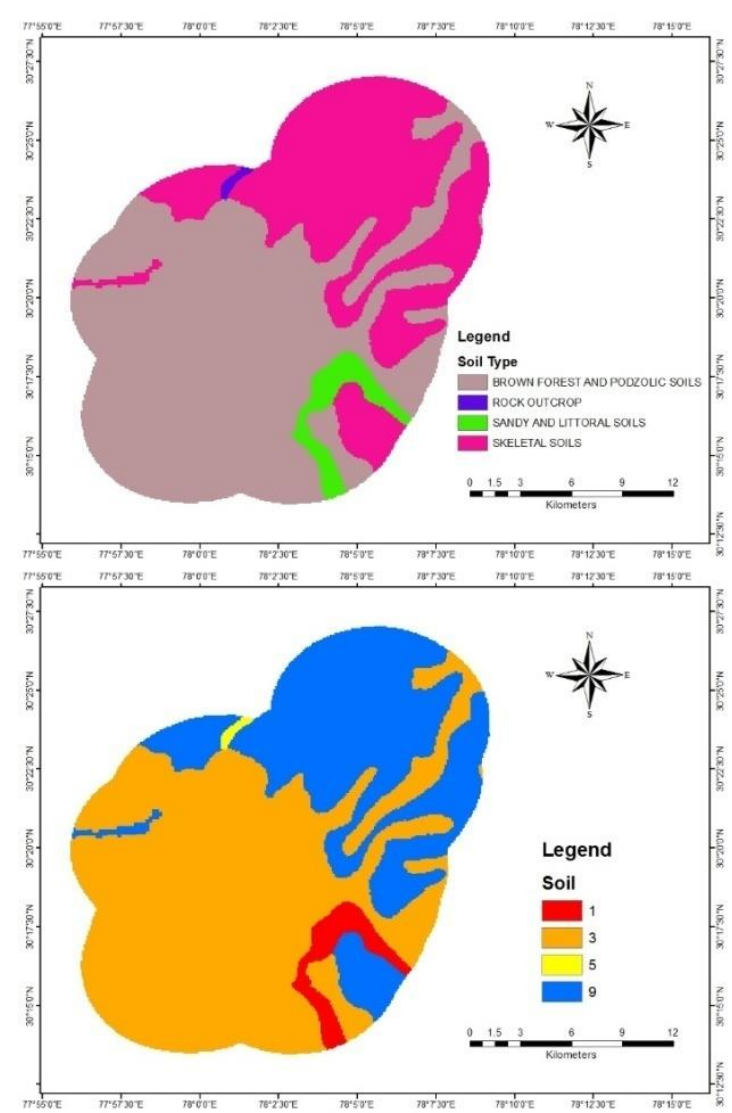

Figure 3. Soil type Suitability Map
4.2.2 Slope sub-criteria: Figure 4 shows the slope map. It has been prepared from Digital Elevation Model (DEM) generated from Cartosat-1 stereo pair satellite data. The slope has been divided into five classes and given suitability weights ranging from 1 to 9 as listed in table 4 . The slope is as important as soil type for determining the suitable site for solid waste disposal as it directly influences runoff. The steeper slope will lead to larger runoff volumes, thereby increasing the chances of disposed of solid waste getting washed down the slope along with runoff creating problems for people living in adjacent areas.

\begin{tabular}{|l|c|}
\hline Slope (\%) & Suitability Score \\
\hline $0-3$ & 9 \\
$3-5$ & 7 \\
$5-10$ & 5 \\
$10-15$ & 3 \\
$>15$ & 1 \\
\hline
\end{tabular}

Table 4. Suitability Scores given for slope range
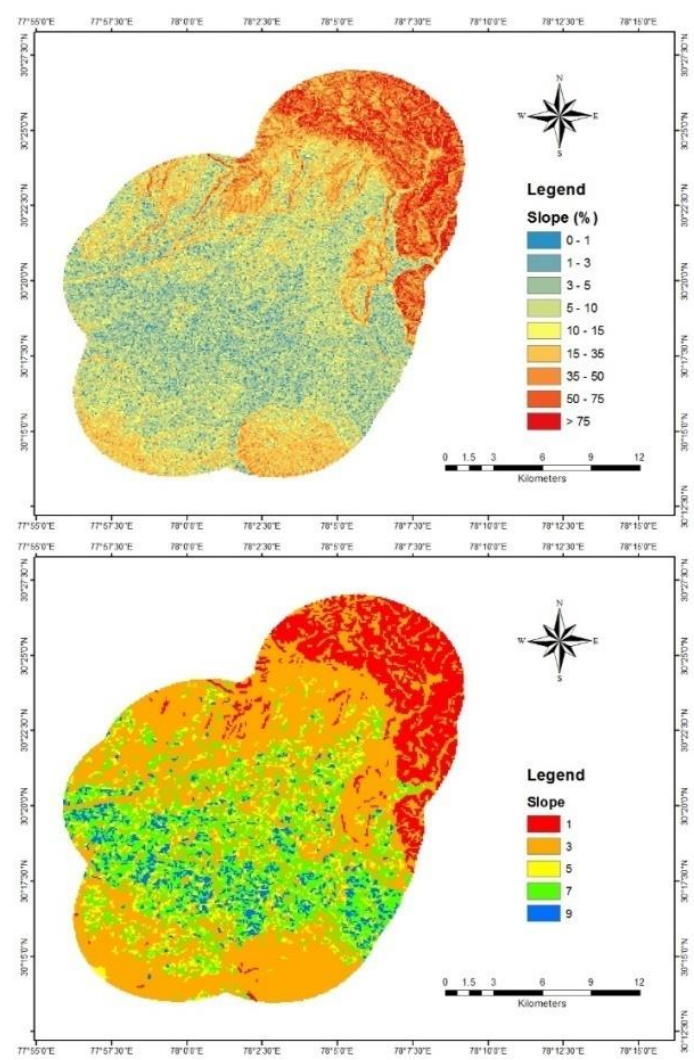

Figure 4. Slope Suitability Map

4.2.3 Geomorphology sub-criteria: Geomorphology map has been sourced from GSI and suitability scores from 1 to 9 as given in Table 5 have been applied spatially (Figure 5). Geomorphology is directly linked to ground water table, and hence an important factor in deciding the suitable site for solid waste disposal. Less the percolation, more suitable is the site, so the pre-tertiary denudational hills have been considered most suitable for dumping solid waste. 


\begin{tabular}{|l|c|}
\hline Geomorphology & $\begin{array}{c}\text { Suitability } \\
\text { Score }\end{array}$ \\
\hline $\begin{array}{l}\text { Channel bar, river/stream, river scarp faces, river } \\
\text { terraces, landslide zones, talus deposit, up } \\
\text { shiwalik highly dissected structural hill, doon fan } \\
\text { gravel dissected hill }\end{array}$ & 1 \\
$\begin{array}{l}\text { Sun recent fan terrace, doon fan gravel dissected } \\
\text { hill }\end{array}$ & 3 \\
Middle shiwalik mod dissected structural hill & 5 \\
Pre-tertiary denude structural hill & 9 \\
\hline
\end{tabular}

Table 5. Suitability Scores given for different geomorphology
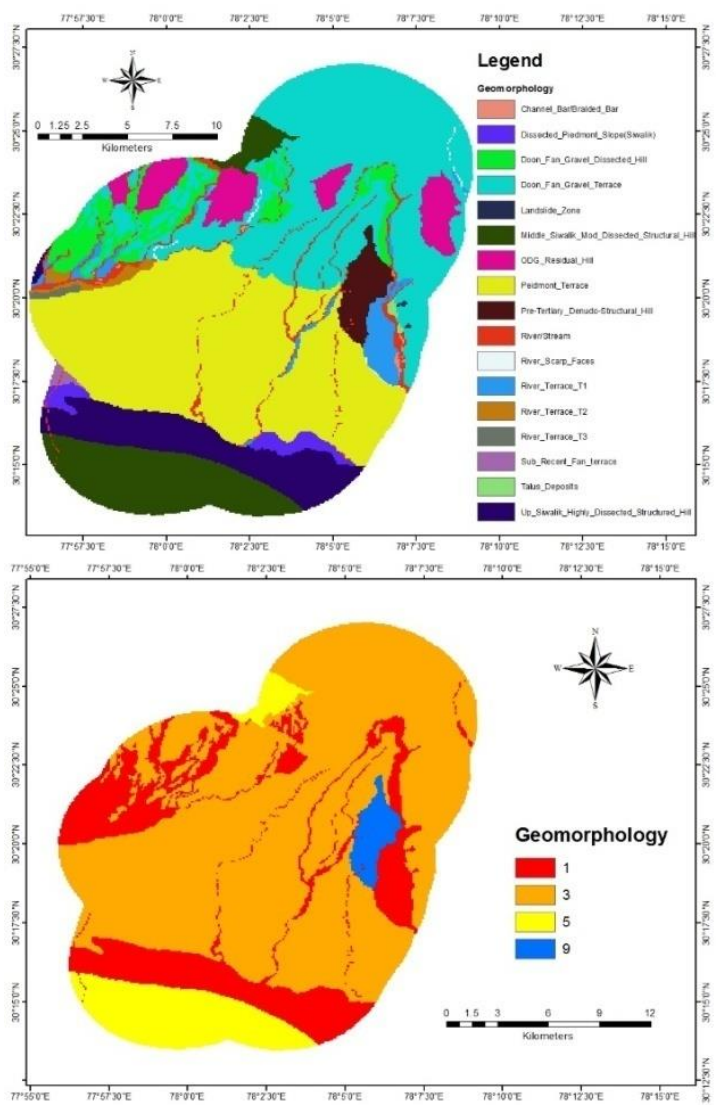

Figure 5. Geomorphology suitability map

4.2.4 Lithology sub-criteria: Lithological map is also sourced from GSI and different suitability scores (Table 6) are applied to each class as shown in Figure 6. Lithology also governs seepage and controls offers protection to underground water table. Pre-tertiary rocks allow least seepage, hence are most suitable for solid waste disposal site and rivers, talus deposits, fan gravel, etc. is least suitable.

\begin{tabular}{|l|c|}
\hline Lithology & Suitability Score \\
\hline Doon fan gravel & 1 \\
Old Doon gravel, upper shiwaliks & 3 \\
Middle shiwaliks & 7 \\
Pre-tertiary & 9 \\
\hline
\end{tabular}

Table 6. Suitability Scores given for different Lithology

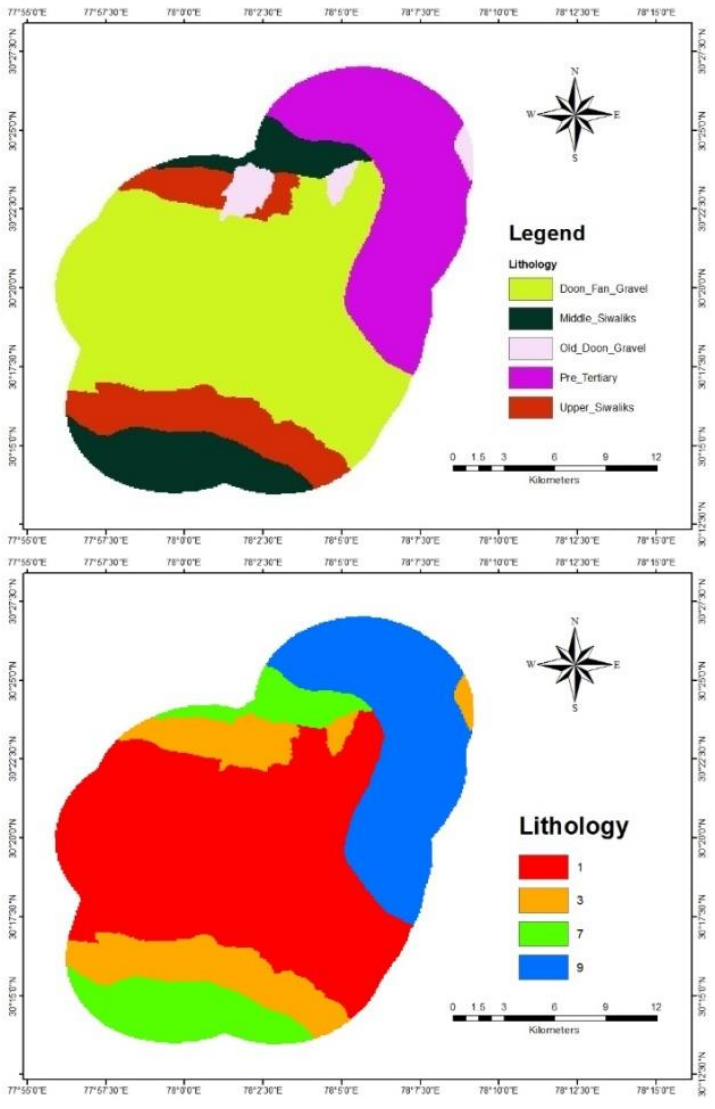

Figure 6. Lithology suitability map

4.2.5 Land Use/ Land Cover sub-criteria: LULC map (Figure 7) was prepared by supervised classification of Cartosat-1 and LISS IV merged images. And different scores as given in Table 7 were applied on it. LULC drives the site selection for solid waste disposal as areas under forest, water bodies, cropland and built-up are best avoided and only open areas such as scrub land or waste lands are suitable.

\begin{tabular}{|l|c|}
\hline Land Use/ Land Cover & Suitability Score \\
\hline Water body, Cropland, Forest & 1 \\
Built-up & 3 \\
Scrub land & 9 \\
\hline
\end{tabular}

Table 7. Suitability Scores given for different LU/LC 

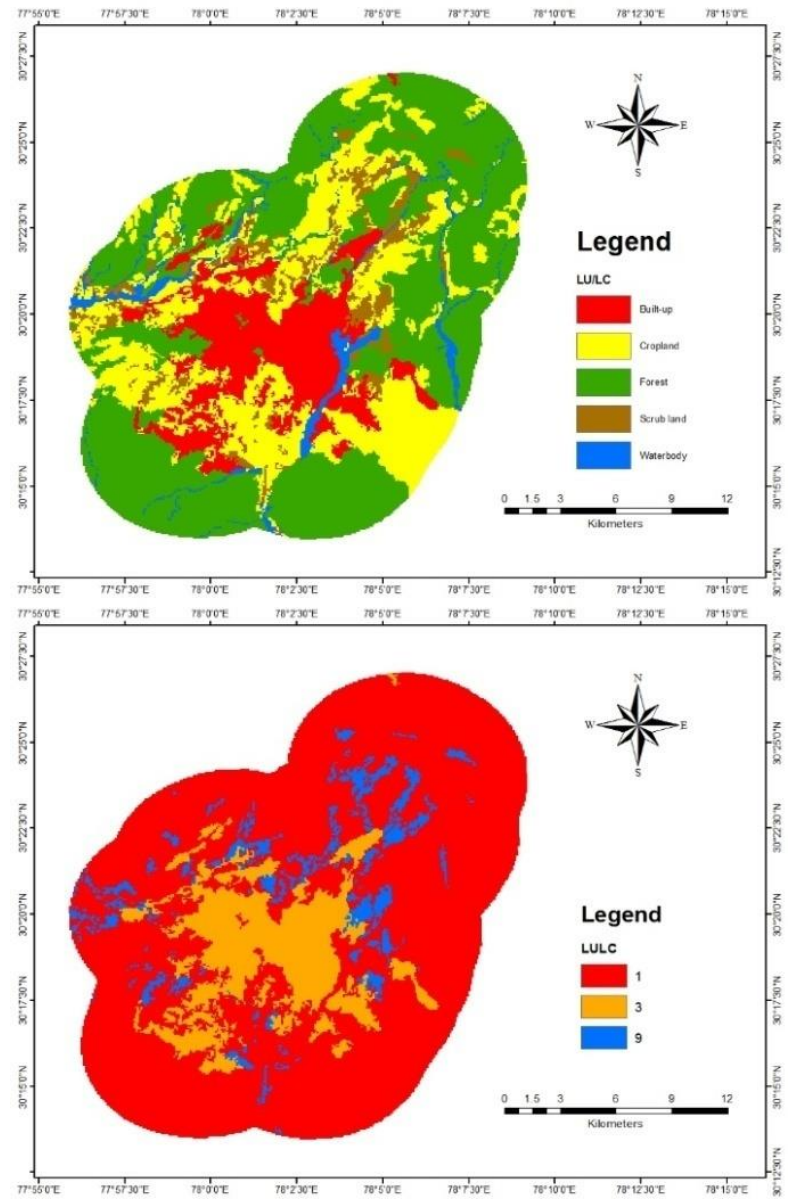

Figure 7. LU/LC suitability map

4.2.6 Drainage sub-criteria: Figure 8 shows the natural drainage map of Dehradun prepared from LISS IV imagery and SOI Toposheet. Multiple ring buffers were created to give suitability scores according to the distance from the drainage as given in table 8.

\begin{tabular}{|l|c|}
\hline Distance from drainage (m) & Suitability Score \\
\hline 500 & 1 \\
1000 & 3 \\
2000 & 5 \\
3000 & 7 \\
5000 & 9 \\
\hline
\end{tabular}

Table 8. Suitability Scores given for drainage
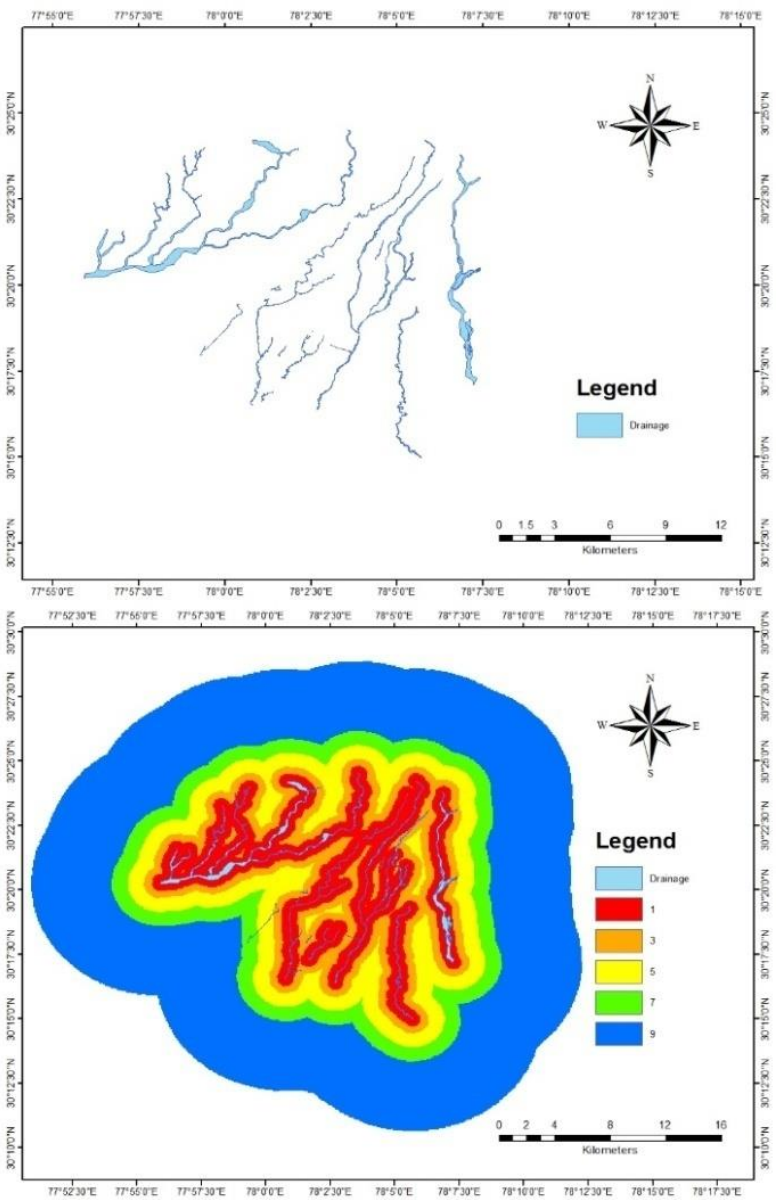

Figure 8 . Suitability map according to distance from drainage

\subsection{Choice Phase}

Finally, after allocation of weights using AHP, Weighted Overlay Analysis and TOPSIS analysis was performed for identification and prioritization of suitable solid waste disposal sites.

4.3.1 AHP -Weighted Overlay based site suitability analysis: Saaty's pair wise comparison matrix (Saaty, 1980) was generated and is shown in Table 9. After weights were derived using comparison and normalized matrix shown in Table 10, the consistency ratio was also calculated to check the consistency of the matrix. For the matrix to be consistent the CR should be less than 0.1(Malczewski, 1999). In this study the CR obtained was 0.01 , which is well inside the permitted range.

\begin{tabular}{|c|c|c|c|c|c|c|}
\hline Classes & Soil & $\begin{array}{l}\text { Slo } \\
\text { pe }\end{array}$ & $\begin{array}{c}\text { Lithol } \\
\text { ogy }\end{array}$ & $\begin{array}{l}\text { Geomor } \\
\text { phology }\end{array}$ & $\begin{array}{l}\text { LU } \\
\text { LC }\end{array}$ & $\begin{array}{c}\text { Drain } \\
\text { age }\end{array}$ \\
\hline Soil & 1 & 1 & 3 & 3 & 3 & 5 \\
\hline Slope & 1 & 1 & 3 & 3 & 3 & 5 \\
\hline Lithology & $1 / 3$ & $1 / 3$ & 1 & 1 & 1 & 3 \\
\hline $\begin{array}{l}\text { Geomorp } \\
\text { hology }\end{array}$ & $1 / 3$ & $1 / 3$ & 1 & 1 & 1 & 3 \\
\hline LULC & $1 / 3$ & $1 / 3$ & 1 & 1 & 1 & 3 \\
\hline Drainage & $1 / 5$ & $1 / 5$ & $1 / 3$ & $1 / 3$ & $1 / 3$ & 1 \\
\hline $\begin{array}{l}\text { Column } \\
\text { Totals }\end{array}$ & 3.20 & 3.20 & 9.33 & 9.33 & 9.33 & 20.00 \\
\hline
\end{tabular}

Table 9. Pair wise Comparison Matrix 


\begin{tabular}{|c|c|c|c|c|c|c|c|}
\hline Classes & Soil & $\begin{array}{c}\text { Slop } \\
\text { e }\end{array}$ & $\begin{array}{c}\text { Lith } \\
\text { olog } \\
\text { y }\end{array}$ & $\begin{array}{c}\text { Geom } \\
\text { orpho } \\
\text { logy }\end{array}$ & $\begin{array}{l}\text { LU } \\
\text { LC }\end{array}$ & $\begin{array}{c}\text { Drain } \\
\text { age }\end{array}$ & $\begin{array}{l}\text { Wei } \\
\text { ghts }\end{array}$ \\
\hline Soil & 0.31 & 0.31 & 0.32 & 0.32 & 0.32 & 0.25 & 0.30 \\
\hline Slope & 0.31 & 0.31 & 0.32 & 0.32 & 0.32 & 0.25 & 0.30 \\
\hline Lithology & 0.10 & 0.10 & 0.10 & 0.10 & 0.10 & 0.15 & 0.11 \\
\hline $\begin{array}{l}\text { Geomorp } \\
\text { hology }\end{array}$ & 0.10 & 0.10 & 0.10 & 0.10 & 0.10 & 0.15 & 0.11 \\
\hline LULC & 0.10 & 0.10 & 0.10 & 0.10 & 0.10 & 0.15 & 0.11 \\
\hline Drainage & 0.06 & 0.06 & 0.03 & 0.03 & 0.03 & 0.05 & 0.04 \\
\hline $\begin{array}{l}\text { Column } \\
\text { Totals }\end{array}$ & 1.00 & 1.00 & 1.00 & 1.00 & 1.00 & 1.00 & 1 \\
\hline
\end{tabular}

Table 10. Normalized Matrix

Consistency Index (CI) is given by equation 1 and Consistency Ratio (CR) is given by equation 2 .

$$
\mathrm{CI}=\frac{(\max -\mathrm{n})}{(\mathrm{n}-1)}
$$

Where, $\lambda_{\max }=$ average of consistency vector; $\mathrm{n}=$ number of compared elements

$$
C R=\frac{C I}{R I}
$$

Where, RI $=$ Randomness Index, RI $=1.24$ for $\mathrm{n}=6$ (Saaty, 1977).

\begin{tabular}{|c|c|c|c|}
\hline Consistency Vector & $\lambda$ max & $\begin{array}{c}\text { Consistency } \\
\text { Index (CI) }\end{array}$ & $\begin{array}{c}\text { Consistency } \\
\text { Ratio (CR) }\end{array}$ \\
\hline 6.093 & 6.061 & 0.012 & $\mathbf{0 . 0 1 0}$ \\
\hline 6.093 & \multicolumn{2}{|c}{} \\
\cline { 1 - 1 } 6.049 & \multirow{2}{|}{} \\
\cline { 1 - 1 } 6.049 & & \\
\cline { 1 - 1 } 6.049 & & \\
\cline { 1 - 1 } 6.017 &
\end{tabular}

After calculation of weights each raster layer was multiplied with its respective weight and then added using Raster Calculator in ArcMap and final suitability map is obtained which is then reclassified using reclassify operation into four classes namely not suitable, moderately suitable, suitable and highly suitable as shown in Figure 9.
4.3.2 AHP - TOPSIS based Site suitability analysis: A site suitability model was prepared using model maker module in ERDAS Imagine. The model was built in such a way that all the derived outputs must be of the same spatial extent as the area of interest. Although the TOPSIS method can be implemented in the raster and vector GIS environments, the technique is especially suitable for raster data structure (Pereira and Duckstein, 1993) also raster operations perform better than vector operations in suitable site analysis. Therefore all thematic layers were generated in raster format. Also, all the derived outputs were brought to a common measurement scale with high scores for more suitable areas and vice versa. TOPSIS technique defines the best alternative as the one that is simultaneously closest to the ideal alternative and farthest away from the negative ideal point.

The GIS based procedure involves the following steps: (Malczewski, 1999; Demesouka et. al., 2013)

1. Determine the set of feasible alternatives.

2. Standardize each attribute map layer by transforming the various attribute dimensions to unidimensional attributes; this transformation allows for comparison of the various layers.

3. Define the weights assigned to each attribute; the set of weights must be such that, $0<=\mathrm{w}_{\mathrm{i}}<=1$ and $\sum_{\mathrm{i} \mathrm{w}_{\mathrm{i}}}=1$.

4. Construct the weighted standardized map layers by multiplying each value of the standardized attribute layer by the corresponding weight; each cell of layers contains the weighted standardized value.

5. Determine the maximum value $\left(\mathrm{v}_{+\mathrm{j}}\right)$ for each of the weighted standardized maps (the values determine the ideal point).

6. Determine the minimum value $\left(\mathrm{v}_{-\mathrm{j}}\right)$ for each of the weighted standardized maps (the values determine the negative ideal point).

7. Using a separation measure, calculate "the distance" between the ideal point and each alternative; a separation can be calculated using the Euclidean (straight-line) distance metric (Equation 3).

$$
S_{i+}=\left[\Sigma_{i}\left(v_{i f}-v_{+f}\right)^{2}\right]^{u, b}
$$

8. Using the same separation measure, determine "the distance" between the negative ideal point and each alternative (Equation 4).

$$
s_{i-}=\left[\sum_{i}\left(v_{i f}-v_{-j}\right)^{2}\right]^{u_{b}}
$$

9. Calculate the relative closeness to the ideal point $\left(\mathrm{c}_{\mathrm{i}+}\right)$ using the equation 5 .

$$
C_{i++}=\frac{S_{i-}}{\left(S_{i+}+S_{i-}\right)}
$$

10. Rank the alternatives according to the descending order of relative closeness to ideal point; the alternative with the highest value of relative closeness to ideal point is the best alternative. 


\section{RESULTS AND DISCUSSION}

In this study two different decision rules of MCDA, i.e. Weighted Overlay and TOPSIS were applied to find out the suitable sites for solid waste disposal in Dehradun and area surrounding it. AHP technique was used to quantify the data and derive the weights which were fed into the numerical models. The outputs of both the techniques are shown in Figure 9 and Figure 10. Both the techniques give similar results and identified suitable areas for waste disposal on the western part of the muncipal boundary of the city within the $5 \mathrm{~km}$ buffer taken to the city limits for easy transport of waste to the sites. Some pockets were also identified in the northern parts but these can be ignored based on the field knowledge of difficult accessibility due to rugged terrain and also other factors which were not taken into consideration into the study like earthquake risk and fault zones existing over this area, etc.

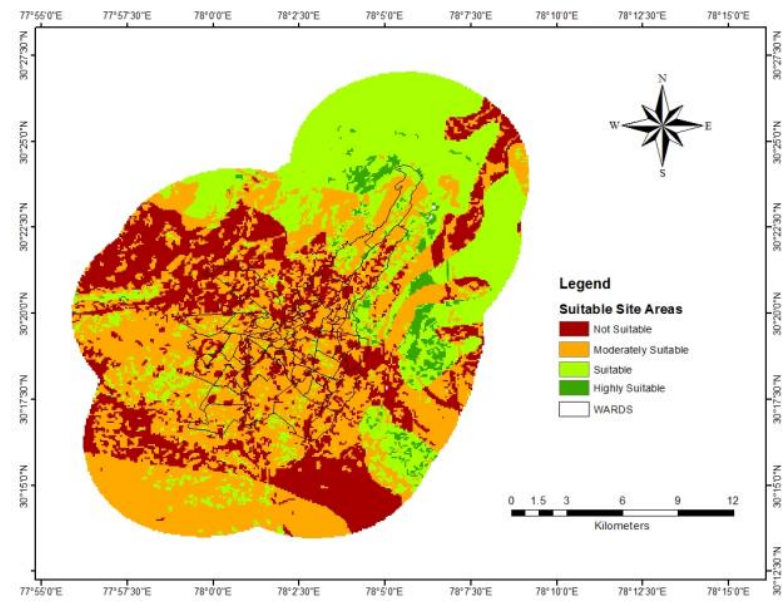

Figure 9. Suitable sites for solid waste disposal (AHP-WLC)

AHP-weighted overlay technique has long been used for site suitability studies and can be found abundantly in the available literature because of its merits of simplicity and ability to incorporate many variables in one single output. But other techniques like TOPSIS, Compromise Programming, Goal Programming, etc. can be rarely found in in literature for site suitability studies, reason being their complex nature and subjective nature of the ideal points used for calculations of suitable sites and other computational complexions of compatibility with GIS.

In the present study an attempt has been made to conceptually apply the TOPSIS technique to identify the suitable sites for waste disposal and compare the results obtained by weighted overlay method. Although, similar outputs were obtained and comparitive judgement cannot be made about which one is better or worse as both methods give only perspective outputs only depending on accuracy of data fed in the models. But, theoretically it is justified that TOPSIS technique is better because it takes into account the ideal and anti ideal situations and gives output based on both of them rather only one like in WLC. Also, the only current dumping site of Dehradun Municipal Corporation lies on the Western Boundary of the city only, so the results obtained can somewhat be validated and considered to be accurate, though exact estimate of the accuracy is not possible.

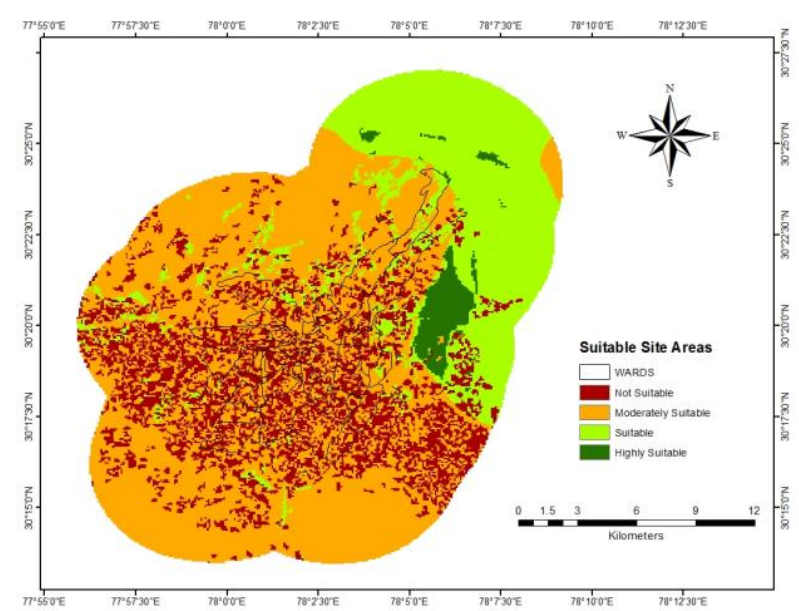

Figure 10. Suitable sites for solid waste disposal (AHPTOPSIS)

Further scope of the study include application of other MCDA decision rules like Compromise Programming, Goal Programming, Multi-Attribute utility theory, etc that can be applied in spatial domain and results be cross validated to further strenthen the case of use of MCDA and Geospatial technologies for Site Suitability applications.

\section{CONCLUSION}

Solid waste disposal is becoming a menace nowadays for the civic authorities all over the country. They are lacking scientific ideas to deal with the situation. Here, Geospatial technologies like Remote Sensing and GIS come into the picture for problems such as site selection for solid waste in proximity of the city. High resolution satellite data can be used to derive unbiased data for solving problems which are complex and thus can help in decision making and scientific planning avoiding environmental degradation and social concerns. GIS is a powerful tool and when combined with accurate input data can reap accurate and sophisticated output which is spatial in nature, hence practically more applicable and can visually please the decision makers. Thus, with geospatial technologies combined with different multi criteria decision analysis algorithms like AHP, TOPSIS, WLC, etc. can help in site selection for municipal solid waste disposal in a more scientific manner and can lead to efficient planning based on concrete evidence.

\section{REFERENCES}

Ahmed, S. M., Muhammad, H. and Sivertun, A., 2006. Solid waste management planning using GIS and Remote sensing technologies: case study Aurangabad city, India. Advances in Space Technologies, International Conference, pp. 196-200.

Babalola, A., 2011. Selection of Landfill Sites for Solid Waste Treatment in Damaturu Town using GIS techniques. J. Environ. Prot., 2(1), pp. 1-10.

Demesouka, O. E., Vavatsikos, A. P., Anagnostopoulos, K. P., 2013. Suitability analysis for siting MSW landfills and its Multicriteria spatial decision support system: Method, 
implementation and case study. Waste Management, 33, pp. $1190-1206$

JNNURM, Solid waste management toolkits, 2012.

Mohd, S., 2011. Waste Management in an urban Area, B.R. Publishers, Dariyaganj, New Delhi.

Malczewski, J., 1999. GIS and Multicriteria Decision Analysis. John Wiley \& Sons Inc., USA.

Pereira, J.M.C., and L. Duckstein., 1993. A multiple criteria decision making approach to GIS-based land suitability evaluation. International Journal of Geographical Information Systems, 7(5), pp. 407-424.

Saaty TL., 1977. A scaling method for priorities in hierarchical structures. J Math Psychol, 15, pp. 231-281.

Saaty TL., 1980. The analytical hierarchical process. New York: McGraw Hill.

Sai Krishna, V., Pandey, K., Karnatak, H., 2017. Geospatial multicriteria approach for solid waste disposal site selection in Dehradun City, India. Current Science, 112(3), pp. 549-559.

World Bank Group. 2017. Global Economic Prospects, June 2017: A Fragile Recovery. Washington, DC: World Bank. (C) World Bank.

https://openknowledge.worldbank.org/handle/10986/26800

License: CC BY 3.0 IGO. 